\title{
Advances and visions in large-scale hydrological modelling: findings from the 11th Workshop on Large-Scale Hydrological Modelling
}

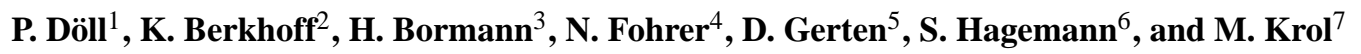 \\ ${ }^{1}$ Institute of Physical Geography, University of Frankfurt, Germany \\ ${ }^{2}$ Institute of Environmental Planning, Leibniz University Hanover, Germany \\ ${ }^{3}$ Department of Biology and Environmental Sciences, Carl von Ossietzky University Oldenburg, Germany \\ ${ }^{4}$ Department of Hydrology and Water Resources Management, Ecology Centre, Christian-Albrechts-University Kiel, \\ Germany \\ ${ }^{5}$ Research Domain of Impacts and Vulnerabilities, Potsdam Institute for Climate Impact Research, Germany \\ ${ }^{6}$ Department Land in the Earth System, Max Planck Institute for Meteorology Hamburg, Germany \\ ${ }^{7}$ Department of Water Engineering and Management, University of Twente, The Netherlands
}

Received: 26 May 2008 - Revised: 1 October 2008 - Accepted: 16 October 2008 - Published: 22 October 2008

\begin{abstract}
Large-scale hydrological modelling has become increasingly wide-spread during the last decade. An annual workshop series on large-scale hydrological modelling has provided, since 1997, a forum to the German-speaking community for discussing recent developments and achievements in this research area. In this paper we present the findings from the 2007 workshop which focused on advances and visions in large-scale hydrological modelling. We identify the state of the art, difficulties and research perspectives with respect to the themes "sensitivity of model results", "integrated modelling" and "coupling of processes in hydrosphere, atmosphere and biosphere". Some achievements in large-scale hydrological modelling during the last ten years are presented together with a selection of remaining challenges for the future.
\end{abstract}

\section{Introduction}

Since 1997, a series of annual workshops on large-scale hydrological modelling has provided a forum to the Germanspeaking community for discussing recent developments and achievements in this research area (Bronstert et al., 1998; Fohrer and Döll, 1999; Gerold, 2000; Sutmöller and Raschke, 2001; Stephan et al., 2002; Hennrich et al., 2003; Ludwig et al., 2004; Krause et al., 2005; Barthel et al., 2006; Lindenschmidt et al., 2007). Here, "large-scale" refers ap-

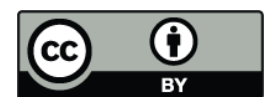

Correspondence to: P. Döll (p.doell@em.uni-frankfurt.de) proximately to study areas between a few thousand $\mathrm{km}^{2}$ and the whole globe. The interest for large-scale hydrological modelling has increased during the last decade due to the need to sustainably manage large river basins (e.g. according to the European Water Framework Directive) but also due to the pervasive global environmental change. The aim of the 2007 workshop $^{1}$ was to evaluate the current state of large-scale hydrological modelling, focusing on the same four themes as in 1998:

1. Sensitivity of model results to uncertainty in input data,

2. Sensitivity of model results to spatial discretisation and information density,

3. Approaches to integrated modelling (integrating natural and social sciences, or water quality and quantity),

4. Coupling of processes in hydrosphere, atmosphere, and biosphere.

Each theme was discussed based on the following three questions:

1. What is the state of the art in large-scale hydrological modelling?

2. Which difficulties and uncertainties exist?

3. What are the perspectives, and what further research is needed?

\footnotetext{
${ }^{1}$ The workshop, with 33 participants, was held in KelkheimEppenhain, Germany, from 31 October to 2 November 2007.
}

Published by Copernicus Publications on behalf of the European Geosciences Union. 
Döll and Fohrer (1999) summarised the outcomes of the 1998 workshop along these questions, presenting state of the art and perspectives of large-scale hydrological modelling at that time. The workshop participants agreed that model calibration to river discharge at the basin outlet does not guarantee that other elements of the water cycle are represented well in their spatial heterogeneity. They considered it necessary to quantify the uncertainty of modelling results, and supported the development of both simple conceptual and complex process modelling approaches to learn about the right degree of complexity required to assess the problem of interest. This paper reflects the discussions and presentations of the 2007 workshop and aims at achieving an overview of the current knowledge and perspectives, and of the advances in recent years. During the workshop, each of the four themes was introduced by an overview presentation, and was discussed in four breakout groups as well as in a plenary session at the end of the workshop. Please note that we cannot provide a comprehensive review of all the important scientific contributions to large-scale hydrological modelling of the last decade but necessarily present a subjective selection.

In Sect. 2, we start with an overall look at the advances of large-scale hydrological modelling during the last ten years (focusing on the developments in German-speaking countries), but also at the challenges for the future. In Sect. 3, the three questions posed above are discussed for each of the four research themes, reconsidering the discussions during the workshop. Theme 1 (Sensitivity of model results to uncertainty in input data) and theme 2 (Sensitivity of model results to spatial discretisation and information density) have been merged for this paper, as the topics discussed in these breakout groups were overlapping. In Sect. 3, we also refer to the results of the seven papers that are published in this volume of Advances in Geosciences (Portmann et al., 2008), and were presented at the workshop as posters.

\section{Ten years of large-scale hydrological modelling - achievements made and remaining challenges for the future}

During the last ten years, sensitivity and uncertainty analyses have become much more widespread in hydrological model studies even though no standard procedure exists for the integral analysis of different sources of uncertainty (model structure, model parameters, and input data). More and better software has become available for pre- and post-processing of hydrological modelling, including GIS integration and tools for sensitivity and uncertainty analysis. This software allows to handle more input data and to communicate modelling results better. Computing capacity has increased significantly, a prerequisite for most sensitivity and uncertainty analyses.

The availability and quality of input data for large-scale hydrological modelling have improved significantly. These data include many remote sensing products like precipitation from weather radar and satellites, water mass variations from dynamic gravity measurements (GRACE), lake levels, inundation areas and elevation. On the other hand, these data require large-scale hydrological modelling for interpretation. Other data sets have been derived from existing observations and statistical information, e.g. the Global Map of Irrigation Areas (GMIA) or the Global Lakes and Wetlands Data Set (GLWD).

While in 1998, very few modelling groups worldwide worked on global hydrological issues and the global hydrology and water use model WaterGAP was just being developed (and "exotic" among the catchment hydrology models), 10 years later global hydrology is well established not only by an advanced version of WaterGAP (Döll and Fiedler, 2008) but also by, for example, LPJmL, a dynamic vegetation model which now includes state-of-the-art hydrological modules (Gerten et al., 2004; Rost et al., 2008a). With their range of global hydrology models, Japanese researchers around Taikan Oki (e.g. Oki and Kanae, 2006), and, in the USA, the groups of Dennis Lettenmaier (e.g. Haddeland et al., 2007) and Charles Vörösmarty (e.g. Fekete et al., 2006) help to improve our knowledge about global hydrology, for example with respect to water scarcity and the influence of humans on the freshwater system, including land cover change and reservoirs. Land surface models now include a much improved representation of terrestrial water flows. They are particularly useful for assessing the feedbacks between water and climate even though they are generally still run in an offline-mode, without two-way coupling to the climate model, due to computational cost and the low skill of climate models to simulate observed precipitation. For regional and smaller scales, there exist examples of two-waycoupling, even between atmosphere and groundwater ${ }^{2}$. In 1998 , nutrient $(\mathrm{N}, \mathrm{P})$ transport models only existed at scales up to the river basin scale, while now there are a number of global-scale models (e.g. Wollheim et al., 2008; Seitzinger et al., 2005).

Finally, a definite development with respect to the publication language of the Workshops on Large-Scale Hydrological Modelling can be observed. While ten years ago, the majority of manuscripts, including the overview paper of Döll and Fohrer (1999) were written in German, all manuscripts are now in English (Portmann et al., 2008). This reflects the wish of the German-speaking community of large-scale hydrological modellers to communicate their results internationally.

Many challenges remain that need to be tackled in the future to improve the significance of large-scale hydrological modelling. At the 1998 workshop, the research need to develop general and transferable rules for spatial scaling and discretisation was identified. The goal was to avoid that

\footnotetext{
${ }^{2}$ AGU Fall Meeting 2007, session H24D, http://www.agu. org/meetings/fm07/fm07-sessions/fm07_H24D.html (last accessed 3 September 2008)
} 
time-consuming sensitivity analyses with respect to spatial discretisation, requiring spatially highly resolved information, had to be done for each new investigation area. However, until now, nobody has come up with general rules; moreover, research on the topic of scaling has only shown that sensitivities to spatial and temporal resolution are modeland area-specific (see also Zhang et al., 2008; Bormann et al., 2008).

With respect to data, quantifying of and coping with the uncertainty in precipitation remains the major challenge for large-scale hydrological modelling. Uncertainty is due to observation density, spatial and temporal interpolation methods and measurement errors but also, in the case of climate change studies, due to the low skill of climate models in computing precipitation. Soil moisture information derived from satellites remains very difficult to use. Even though efforts to measure soil moisture from space began more than 10 years ago, until now, the low effective soil depth for which the measurements are representative (a few centimetres) and the impossibility to measure soil moisture under forest canopies has hindered the wide-spread application of these data in large-scale hydrological modelling (compare Wagner et al., 2003, 2007). Still more efforts should be spent on increasing data availability, improving data quality and filling gaps in historic data sets, e.g. by running global data centres. It is absolutely necessary to maintain the existing hydrological and meteorological measurement networks in order to collect continuous time series for the analysis of hydrological change.

With respect to coupling, the large grid cell sizes of climate models, which have not decreased much during the last ten years, still make coupling to terrestrial hydrology difficult, at least at the global scale. At the regional scale, where regional atmospheric models can be run at approximately $10 \mathrm{~km}$ spatial resolution, coupling is limited by the length of the simulated time periods. While hydrological models (except flood models) focus on years to decades, regional atmospheric models are run for days to several weeks only. Continued efforts to extend coupled or integrated modelling are required to address many urgent societal problems (e.g. climate change, water for nature, water for food).

A major challenge is to find efficient ways to analyse the extensive output of large-scale hydrological models or coupled/integrated models, and to present the results in a transparent way to the intended audience. Communication of the uncertainty of model results to clients and the public is also crucial but challenging.

To successfully set up and run models as part of a learning process (about the system and how it changes) requires developing new approaches where continued observation and modelling go hand in hand (Beven, 2007). Post-audits are a means to learn from past model predictions. Large-scale models can be the basis for "integrated environmental models of everywhere", if they can be refined for the specific place of interest when more detailed data and improved process knowledge become available (Beven, 2007). Thus, we could formulate as a challenge for future large-scale modelling to set up models in such a flexible way that 1) different processes/compartments can be switched on or off and 2) nesting of finer-scale models within large-scale models is possible, such that also the information available at larger scales (or in the environment of the nested area) can be taken into account. In addition, further work on scaling behaviour and parameterization of sub-scale variability is needed. Such approaches would enable modellers to use appropriate process descriptions and complexity for different regions, scales or goals of a study.

\section{Specific findings for the themes "sensitivity of model results", "integrated modelling" and "coupling of processes in hydrosphere, atmosphere and biosphere"}

The workshop participants focused on discussing, in breakout groups but also in the plenary, state of the art, difficulties encountered and research perspectives for the themes "sensitivity of model results", "integrated modelling" and "coupling of processes in hydrosphere, atmosphere and biosphere". The results of this work are summarised this section.

\subsection{Sensitivity of model results}

Model results are sensitive to

1. input data (including spatially and temporally varying model forcing like climate and emissions, spatially varying soil and vegetation characteristics as well as model parameters), which can be uncertain due to measurement, interpolation and other errors

2. spatial and temporal discretisation of the model and the information density of input data

3. model structure.

\subsubsection{State of the art}

In hydrological modelling, model calibration against observed river discharge has traditionally been a popular method to increase model skill, by identifying a set of parameters that results in the best fit to observed discharge. It is now recognised, however, that this kind of calibration is not likely to significantly reduce uncertainty and to result in deterministic predictions that form an appropriate basis for water management decisions. By adjusting a large number of parameters, it might be possible to obtain a good fit even if the model structure is not appropriate, such that calibration may even prevent an improved system understanding. While equifinality (different parameter sets leading to very similar computed river discharge, Franks et al., 1997) is a major problem, there are many other challenges, including the need to predict other variables of the water cycle like 
evapotranspiration and the need to assess the hydrological behaviour of ungauged basins.

Therefore, sensitivity and uncertainty analyses are generally regarded as a necessary means to obtain an improved understanding of the model and the modelled system. Thus, it is state of the art to try to characterise model sensitivities (but mostly only a rather restricted subset of all sensitivities) such that deterministic model results can be complemented by qualitative or quantitative uncertainty estimates.

Today, many methods as well as software tools for sensitivity analyses are available. They can be grouped into rather simple local methods like those implemented in the software package PEST (Doherty and Johnston, 2003; http: //www.sspa.com/pest/), which only compute the sensitivity to one parameter at a time, and more complex and computationally expensive global methods (mainly Monte-Carlo analyses), which account for parameter correlations and allow to determine the most sensitive parameters (Saltelli et al., 2000; Kaspar, 2003; Tang et al., 2007). SimLab (http://simlab.jrc.ec.europa.eu/) is a state-of-the-art, free development framework for sensitivity and uncertainty analysis. For simple hydrological models, global sensitivity and uncertainty analysis can be combined with model calibration (Muleta and Nicklow, 2005). Besides, straightforward graphical representations of differences in model output remain popular to show sensitivities of model output to uncertain spatially and temporally varying model forcings like precipitation (Döll and Fiedler, 2008) and model structure (Zhang et al., 2008). Tools for quantitative comparisons of gridded data are available (Visser and de Nijs, 2006).

Spatial model discretisation can, but need not, affect model results significantly. Model discretisation often is chosen according to the spatial resolution of the available input data, but effects of changes in model discretisation and spatial resolution of the input data may have different and model-specific effects on the simulation results. It is generally expected that a better spatial resolution of input data increases model performance. Kuo et al. (1999) discussed the effect of different grid sizes on soil water content for a spatially explicit hydrological model. Input data were topography, soil type, and land use, and grid sizes were varied from 10 to $600 \mathrm{~m}$. The authors found that model results showed higher average soil water contents and higher evaporation rates for large grid sizes. Booij (2005) analysed the impact of choosing a different number of sub-catchments on discharge behaviour modelled by the HBV model. The number of subcatchments was 118,15 , and 1 . The fit of modelled to observed discharge only improved slightly if the catchment was subdivided. Bormann et al. (2008) compared the effect of input data resolution (50 to $2000 \mathrm{~m}$ ) on simulated catchment water flows of three hydrological models: SWAT (Arnold et al., 1998), WASIM (Schulla, 1997) and TOPLATS (PetersLidard et al., 1997). The study revealed that different models showed different sensitivities to data resolution. While the grid-based models showed acceptable results up to $500 \mathrm{~m}$ grid size, the SWAT model (which is based on hydrological response units and subcatchments) was more sensitive resulting in a threshold of $200 \mathrm{~m}$ grid size. Subcatchment discretisation was assumed to be the main reason for the higher sensitivity of SWAT.

Chaplot (2005) investigated the impact of spatial information density on hydrological model results. Looking at DEMs with spatial resolutions from 20 to $500 \mathrm{~m}$ and soil maps at scales of 1:25000, 1:250000 and 1:500 000 he found that model results did not improve for DEM grid sizes of $50 \mathrm{~m}$ and smaller. High-resolution soil maps were more important for modelling nitrogen and sediment yields than for modelling runoff. Barthold et al. (2008) and Petersen et al. (2008) presented approaches for dealing with uncertainties resulting from low information density. Using geochemical data, Barthold et al. (2008) made a first step to identify dominant hydrological pathways and processes in a datapoor region in Mongolia. Petersen et al. (2008), using a hydrological model, employed lake level time series and macroscale precipitation data to extrapolate flows of the river Nile into the Sudd Swamps after 1983, when gauge observations stopped.

Weiß and Menzel (2008) and Zhang et al. (2008) analysed the uncertainties related to model structure. Weiß and Menzel (2008) found significant differences between global scale estimates of potential evapotranspiration derived by four different methods, but available information did not facilitate identification of the best estimation method. For the Jordan River basin, they showed the large uncertainty of actual evapotranspiration as computed by either the WaterGAP Global Hydrology Model (Döll et al., 2003) or the regional model TRAIN (Menzel, 1999). For two basins that were modelled in a lumped manner, Zhang et al. (2008) explored the impact of model structure by comparing model results that were obtained by different combinations of modules (which also reflected different spatial resolutions of input data) to time series of observed river discharge. They found that models with only one module in addition to the basic model structure showed - almost - the best performance, and neither the simplest models nor the models with a large number of additional modules. Both the appropriate basic model structure and the additional module were observed to be catchment specific, and the additional modules were assumed to represent regionally different but important hydrological processes. Their results are consistent with the idea of "appropriate complexity" for modelling, as additional processes, even if well understood in general, lead to the need to estimate even more location-specific model parameters (Beven, 2007).

A new way to quantify model output uncertainties due to a combination of the three uncertainty categories given above is to analyse multi-model ensembles. In the framework of global climate change and its impacts on terrestrial water (runoff, soil moisture), the results of climate model runs from a variety of models (and model runs) have been 
combined, and the resulting ensemble mean changes are enhanced by indicators of inter-model variance (Bates et al., 2008; Sect. 2.3). For regional climate models over Europe, the multi-model ensemble mean has been shown to have a better performance than individual model results, and this regional ensemble was used to drive hydrological models (Christensen and Christensen, 2007; Graham et al., 2007; Hagemann and Jacob, 2007). In meso-scale hydrological modelling, multi-model ensembles have been proven to be useful for the reduction of predictive uncertainty as well. Viney et al. (2005) and Bormann et al. (2007) showed that predictions based on simple multi-model ensembles such as the mean or the median of daily discharge predictions outperformed the best individual models calibrated for a mesoscale catchment (Dill basin, Germany, $693 \mathrm{~km}^{2}$ ). Particularly for the validation period, multi-model ensembles reduced the predictive uncertainty by improving performance measures such as Nash-Sutcliffe efficiency, coefficient of determination, root mean squared error and bias.

\subsubsection{Difficulties}

Currently, no advanced methods are available for analysing the sensitivity to spatially distributed model input (e.g. precipitation, irrigated areas), like it is possible for spatially constant parameters and model algorithms with SimLab. This is partially due to the fact that there is not enough information to quantify the spatial correlations of the frequency distributions of grid cell values. Currently, it is only possible to evaluate the different model outputs that result from the use of different distributed input data sets. Another difficulty is to quantify uncertainties related to "soft" expert knowledge and to classifications done by experts (e.g. classifications of soil units). Besides, uncertainties due to spatial and temporal interpolation of point data, e.g. of precipitation measurements, cannot be considered satisfactorily.

To decrease the uncertainty related to model structure, a better understanding about which processes are most relevant at what spatial scales, and how process conceptualisations are related to scale would be necessary but is lacking. In addition, rules for optimal model (and input data) discretisation are missing (but may not be achievable except for specific locations and models).

Data availability and accessibility still are major problems, for example concerning data on groundwater, water use or reservoir management. But also access to basic hydrological data such as precipitation and river discharge partly is still difficult, even if important improvements have been achieved due to data made available by international data centres (Global Precipitation Climatology Centre GPCC, Global Runoff Data Centre GRDC, International Groundwater Resources Assessment Centre IGRAC) and remote sensing (radar altimetry, terrestrial and space-borne precipitation radar, GRACE dynamic gravity fields etc.).

\subsubsection{Research perspectives}

It appears to be necessary to extend and enhance sensitivity and uncertainty analyses in large-scale hydrological modelling. For example, we need to find out how sensitivities change with temporal and spatial scales. Guidelines should be created advising model users which tool is appropriate for which kind of sensitivity and uncertainty analysis. Subsequently, methods could be chosen from a "toolbox" that will likely have to be specific for classes of models (e.g. water quality vs. quantity). Not only complete discharge time series should be analysed, but also characteristic periods, the selection of which depend on the objective of the model application (e.g. drought analysis, flood analysis, water balances). Similar to the case of climate models, ensembles of global and regional hydrology models should be analysed, as such comparisons allow for 1) characterising the uncertainty of model outputs and 2) improving models. A discussion on "rules for good calibration practice" as well as on standard procedures for uncertainty analyses should be initiated within the international hydrological community in order to provide a common methodological inventory for hydrological modelling studies.

Models should be set up in a modular way such that model runs with different modules being switched on, when compared to observed data, can easily help to increase system understanding and the selection of the appropriate model structure (see also Zhang et al., 2008) Such flexible modelling setups would allow modelling to truly become a learning process (Beven, 2007). They do require, however, a thorough consideration of data exchange and calibration procedures as these depend on the selected "switch". Previous efforts for modular modelling systems like MMS-PRMS (Leavesly et al., 2005) need to be reflected critically.

To decrease uncertainty of large-scale hydrological modelling results, new remote sensing information should be taken into account, including data on inland water levels, inundation areas and total water storage changes (the latter are available from the GRACE satellite mission but only at a spatial resolution of $100000 \mathrm{~km}^{2}$, approximately). This also enhances the possibility to calibrate hydrological models not only against discharge at the catchment outlet but also against spatial (and temporal) patterns of hydrological fluxes or state variables, such as evapotranspiration or water storage. Global data centres are needed that provide quality-checked, consistent data, e.g. for lakes, reservoirs, water use and ecology. The metadata should include data uncertainties (as done, for example, for the Global Map of Irrigation Areas, http://www.fao.org/nr/water/ aquastat/irrigationmap/index10.stm). 
3.2 Approaches to integrated modelling (integrating natural and social sciences, or water quality and quantity)

The term integrated modelling, in its narrower sense, can be defined to relate to a coupling of environmental (physical, chemical, biological) models (e.g. hydrological or habitat models) to models that cover systems that are outside the realm of natural sciences (e.g. economic or actor-based models). In the context of the workshop, models that include both water quality and quantity were also discussed.

\subsubsection{State of the art}

Integrated modelling of climate/terrestrial water/water use/land use/agro-economy at the meso-scale (e.g. large river basin, countries or first-order subnational units) is state of the art (e.g. WAVES, Döll and Krol, 2002; Krol et al., 2003; SFB 299, www.sfb299.de; GLOWA projects, www.glowa.org). There are some problems of intrinsic differences in spatial scales, however, e.g. between socio-economic and hydrological spatial units, climate and hydrology or between groundwater and surface water. Within an integrated modelling framework, the hydrological model should be able to compute well all components of the terrestrial water cycle and their variability (e.g. both low flows and high flows, and soil moisture) because it is these components that may specifically drive other parts of the integrated model.

Economic modelling is a popular way to include humans as a component of the water system. However, it is recognised that humans do not always behave such that the overall net benefit is optimised, due to, for example, a more complex set of values, a lack of knowledge, or different world views (Ebenhöh and Pahl-Wostl, 2008). Agent-based modelling (ABM), for which various software tools are available (e.g. CORMAS, http://cormas.cirad.fr; FAMOJA, http: //www.usf.uos.de/projects/famoja/) takes this fact into account. A wide variety of different ABM approaches exist (Hare and Deadman, 2004). Actor-based modelling (Döll and Döll, 2006) with the DANA software (http://dana. actoranalysis.com/) is a type of ABM in which the problem perspective (or world view) of societal actors (i.e. their goals, and the related factors, prospects and possible actions) is analysed. It allows determining, in a semi-quantitative way, the preferred actions of the various actors in the problem field, which can then serve to model the decisions of the actors (agents) and the resulting changes in the environment. Currently, the objective of ABM is not to predict system behaviour but to improve system understanding and learning, in particular during participatory processes. ABM is often applied in the context of land use change modelling (Castella and Verburg, 2007). Actor-based modelling was used to identify sustainable strategies in the problem area of trace compounds in surface waters, as part of an integrated modelling approach which also included a fate and transport model in a mesoscale basin. Thus, it was possible to support the quantification of driving forces in scenario analyses (Döll and Döll, 2008).

Modelling of nitrogen transport and fate is widespread and rather successful at small scales, even though the impacts of wetlands and lakes in lowlands are not well understood (Schmalz et al., 2008). However, extrapolation of different, well-established small-scale models of nitrogen leaching from agricultural soils, including their parameters, to larger scales (tens of thousands of $\mathrm{km}^{2}$ ) leads to very different estimations of leaching (Haberlandt et al., 2002). A few global nitrogen models of varying complexity exist (Seitzinger et al., 2005). Different from smaller scales, a major uncertainty at the global scale is land use including fertiliser input and yield modelling. Currently, water quality models of total nitrogen (Van Drecht et al., 2005), salt and oxygen content of surface waters that are based on the WaterGAP model are being developed.

\subsubsection{Difficulties}

There is a risk of uncertainty accumulation in integrated modelling. Currently, there are no tailored tools for uncertainty analysis in integrated modelling, and there is no integrated modelling study with a comprehensive characterization of uncertainties on a hydrological topic (for a quantitative-qualitative uncertainty assessment on integrated energy models using the NUSAP approach, a method to describe the quality of information, see van der Sluijs et al., 2005). A challenge for integrated assessments is to communicate complex integrated modelling approaches and results in a transparent and client-specific manner.

Water-related societal problems are often linked to the way society deals with extreme events. Therefore, it is important to understand how humans respond, e.g. with respect to water use, or to variable hydrological conditions. For instance, drought-driven increases in crop prices may drive irrigation to increase, enhancing drought impacts.

The future of water resources and quality is strongly dependent on land use. While global and regional land use scenarios have been derived by a variety of land use models, irrigated land use (with a variety of management practices) and its effect on yields and water resources, but also the effect of water availability on irrigated agriculture have not been considered satisfactorily, at least at the global scale.

\subsubsection{Research perspectives}

For analysis of uncertainty due to spatially distributed parameters or input data, hydrologists should seek methodological advice from mathematicians (e.g. to be able to set an error band of $50 \%$ per grid cell and of $10 \%$ per aggregated river basin). The most important output variables of integrated modelling exercises should be validated jointly, and against historic time series if available. 
In integrated modelling, there should be a focus on the effects of coupling of relatively simple model components. Similar to the research needs expressed in Sect. 3.1.3, at least as much effort should be spent on learning from integrated modelling (e.g. on model structure uncertainty) as on improving models. One goal of models (including hydrological, agent- or actor-based, or integrated) is decision support, for example in participatory processes. Research should be performed to see under what conditions modelling actually improves the participatory process and the identification of sustainable strategies.

Agent- or actor-based modelling of e.g. water use may give additional insights to identify key research requirements for large-scale hydrological modelling in the framework of integrated modelling, for example with respect to the representation of variability including floods and droughts (rather than restricting the validation of hydrological models to one overall skill measure). In agent-based modelling, models are regularly constructed in a bottom-up way, unravelling the individual's decision making into series of steps and schematising each of them. The appropriate validation approach for such models should not only concern the representation of the steps but also the plausibility of the resulting behaviour (similar to validation of process-based physical models). More research into how to simulate processes of cognitive and social learning in agent-based modelling would support the identification of sustainable management strategies.

\subsection{Coupling of processes in hydrosphere, atmosphere, and biosphere}

\subsubsection{State of the art}

Coupled models are needed for analysing future changes in hydrological and associated systems, and especially for analysing feedbacks between the hydrosphere and other spheres of the earth system. With respect to coupling hydrosphere, atmosphere and biosphere at large scales in models, it is state of the art that two of the three compartments are coupled (e.g. hydrosphere and terrestrial biosphere in dynamic global vegetation models, Gerten et al., 2004), while only in a few cases atmosphere, hydrosphere and biosphere are all coupled consistently (Raddatz et al., 2007). Land use data remain a necessary input to these coupled models. Some biosphere models can simulate dynamic changes in natural vegetation (Sitch et al., 2003). Water quality is, in general, not taken into account. There is currently no spatially explicit model available which integrates over all ecospheres and the anthroposphere (i.e. a true earth system model). For coupling, either new models have been developed or existing models have been strongly adapted. Adaptation has been necessary to avoid that some processes (e.g. in the soil) are modelled inconsistently or incorrectly, or that they are duplicated.
To assess the impact of hydrological changes on freshwater ecosystems, coupling of hydrological, hydraulic and ecological models is needed. While the coupling of hydrological and hydraulic models is rather well established, the link to aquatic ecology is not. Modelling of habitat requirements and biological changes of freshwater ecosystems at larger scales is only in its infancy, though first global approaches exist (Smakhtin et al., 2004). However, in the case of high data availability, advanced analysis of the relationship between flow regimes and species composition is possible (Kennen et al., 2008). For a macro-scale analysis of environmental water requirements in all of China, Zhang and Döll (2008) could not yet couple ecological impacts to modelled alteration of river flow regimes due to restricted data availability. They only computed river flow alterations that are caused by man-made reservoirs and human water abstraction, to show where habitat quality is severely decreased.

Rost et al. (2008b) examined human alterations of the terrestrial water cycle caused by land management, using a dynamic global vegetation model (LPJmL, Bondeau et al., 2008; Rost et al., 2008a) for both natural vegetation and crops, which includes a good representation of hydrological processes as linked to ecological/biogeochemical processes. This study quantifies past and potential future changes in evapotranspiration and river discharge in response to selected scenarios of land use and climate change.

\subsubsection{Difficulties}

In most cases only a one-way coupling is realised, and model couplings generally need to be improved. Existing models are often not suitable for coupling because of different spatial and temporal scales, and also because model consistency must be maintained. For example, most hydrology models do not compute energy balances, but this is a prerequisite for the coupling to atmosphere models.

There still is a lack of data in terms of input data and validation data for coupled models, especially since these require validation not only of discharge but also of other processes such as leaf phenology or net primary production, for which large areas are unobserved. Also, severe errors occur in observational data. This refers to hydrological as well as nonhydrological data (fertiliser, irrigation, crop type, land use etc.). Currently, data uncertainties cannot be quantified satisfactorily. These circumstances pose a particular problem for the multi-variable validation necessary to test the performance of coupled models.

Direct $\mathrm{CO}_{2}$ effects on transpiration have been characterised well in laboratories and at field scales, but it is still uncertain how to transfer these adequately to larger scales. This is particularly due to interactions with water availability, regional climate, nutrients and ozone. Given this uncertainty, effects of increasing $\mathrm{CO}_{2}$ concentration on transpiration and, thus, on runoff and discharge cannot be quantified with confidence. 
The fraction of photosynthetically active radiation absorbed by vegetation (fPAR) is derived from satellite imagery, but leaf area index (LAI) is requested by many models. Thus global LAI data sets should be provided directly from satellite imagery instead of deriving LAI from secondary satellite products such as global land cover maps (see e.g. Hagemann, 2002).

\subsubsection{Research perspectives}

In coupled modelling, water quality and water temperature are new areas which need further research. Continued efforts should be made to develop the feedback system atmospherehydrosphere-biosphere (including anthropogenic impacts). This encompasses the development of specific data sets (including appropriate interpolation methods). The development of coupled models should be supported by research projects involving several disciplines (like the BALTIMOS project, www.baltimos.de).

Systematic research on model complexity is needed with the aim to select the most appropriate model for a given research question. Ensemble runs are useful to evaluate model performance. Different models, scenarios, input data, and parameters can be used for ensemble analyses. New methods should be developed for separating trend and variability in time series, for processes at different time scales.

Estimation of evaporation from land can be improved by combining modelling with satellite and other data, e.g. soil moisture estimates via GRACE, regionalisation of flux tower observations with the aid of MODIS (Moderate Resolution Imaging Spectroradiometer) data or LAI. In order to achieve an integrated evaluation of the relation between hydrology, hydraulics, and habitat in surface waters, as required, for example, by the EU Water Framework Directive, knowledge about the impact of surface water structure, water quality and streamflow dynamics must be improved. Currently this knowledge exists for selected areas only, and improved methods to link hydrology/hydraulics models and habitat models in data-poor areas need to be developed (Arthington et al., 2006). To accomplish this, interdisciplinary cooperation between hydrological and ecological modellers is necessary.

\section{Final remarks}

This short review on eleven workshops representing more than ten years of research in the field of regional and largescale hydrological modelling in Germany has shown that substantial progress has been made in the description of large-scale hydrological processes. For the themes discussed during the 11th Workshop (uncertain input data, scale effects, integrated modelling and model coupling), workshop participants identified the remaining difficulties as well as promising research perspectives. Further progress in large-scale hydrological modelling will be reviewed in future work- shops. The 12th Workshop on large-scale hydrological modelling will be hosted by Kiel University from 12-14 November 2008 .

Acknowledgements. The authors thank the organisers of the (up to now) eleven workshops on large-scale hydrological modelling (University of Potsdam: 1997, Universities of Gießen and Kassel: 1998, University of Göttingen: 1999, GKSS Geesthacht: 2000, University of Bonn: 2001, UFZ Magdeburg: 2002, University of Munich: 2003, University of Jena: 2004, University of Stuttgart: 2005, GFZ Potsdam: 2006, University of Frankfurt: 2007) for organising the workshops and for selecting burning key questions for every workshop, and the reviewers for their constructive comments.

Edited by: F. Portmann, K. Berkhoff, and M. Hunger

Reviewed by: two anonymous referees and the first editor

\section{References}

Arthington, A. H., Bunn, S. E., Poff, N. L., and Naiman, R. J.: The challenge of providing environmental flow rules to sustain river ecosystems, Ecol. Appl., 16, 1311-1318, 2006.

Arnold, J. G., Srinivasan, R., Muttiah R. S., and Williams, J. R: Large area hydrologic modelling and assessment, Part I: Model development, J. Am. Water Resour. As., 34, 73-88, 1998.

Barthel, R., Götzinger, J., Hartmann, G., Jagelke, J., Rojanschi, V., and Wolf, J.: Preface "Integration of hydrological models on different spatial and temporal scales", Adv. Geosci., 9, 1-1, 2006

Barthold, F. K., Sayama, T., Schneider, K., Breuer, L., Vaché, K. B., Frede, H.-G., and McDonnell, J. J.: Gauging the ungauged basin: a top-down approach in a large semiarid watershed in China. Adv. Geosci., 18, 3-8, 2008, http://www.adv-geosci.net/18/3/2008/.

Bates, B. C., Kundzewicz, Z. W., Wu, S., and Palutikof, J. P.: Climate Change and Water: Technical Paper of the Intergovernmental Panel on Climate Change, IPCC Secretariat, Geneva, 210 pp., 2008.

Beven, K.: Towards integrated environmental models of everywhere: uncertainty, data and modelling as a learning process, Hydrol. Earth Syst. Sci., 11, 460-467, 2007, http://www.hydrol-earth-syst-sci.net/11/460/2007/.

Booij, M. J.: Impact of climate change on river flooding assessed with different spatial model resolutions, J. Hydrol., 303, 176198, 2005.

Bondeau, A., Smith, P., Zaehle, S., Schaphoff, S., Lucht, W., Cramer, W., Gerten, D., Lotze-Campen, H., Müller, C., Reichstein, M., and Smith, B.: Modelling the role of agriculture for the 20th century global terrestrial carbon balance, Glob. Change Biol., 13, 679-706, 2007.

Bormann, H., Breuer, L., Croke, B., Gräff, T., Hubrechts, L., Huisman, J. A., Kite, G. W., Lanini, J., Leavesley, G., Lindström, G., Seibert, J., Viney, N. R., and Willems, P.: Reduction of predictive uncertainty by ensemble hydrological modelling of catchment processes and land use change effects. Proceedings of the 11th Conference of the Euromediterranean Network of Experimental and Representative Basins (ERB), Luxembourg, 20-22 September 2006. IHP-VI/Technical Documents in Hydrology 81, 133-139, 2007. 
Bormann, H., Breuer, L., Croke, B., Gräff, T., and Huisman, J. A.: Assessing the impact of land use change on hydrology by ensemble modelling (LUCHEM) IV: Model sensitivity on data aggregation and spatial (re-) distribution. Adv. Water Resour., 34, 674-695, 2008.

Bronstert, A., Krysanova, V., Schröder, A., Becker, A., and Bork, H.-R.: Modellierung des Wasser- und Stofftransportes in großen Einzugsgebieten. Zusammenstellung der Beiträge des Workshops am 15. Dezember 1997 in Potsdam, PIK-Report, 43, 1998.

Bronstert, A., Güntner, A., Jaeger, A., Krol, M., and Krywkow, J.: Großräumige hydrologische Parametrisierung und Modellierung als Teil der integrierten Modellierung., Modellierung des Wasser- und Stofftransports in großen Einzugsgebieten., in: Modellierung des Wasser- und Stofftransports in großen Einzugsgebieten, edied by: Fohrer, N. and Döll, P., Kassel University Press, 31-40, 1999.

Castella, J. and Verburg, P. H.: Combination of process-oriented and pattern-oriented models of land-use change in a mountain area of Vietnam, Ecol. Model. 202, 410-420, 2007.

Castillo, V. M., Gomez-Plaza, A., and Martinez-Mena, M.: The role of antecedent soil water content in the runoff response of semiarid catchments: a simulation approach, J. Hydrol., 284, 114130, 2003.

Chaplot, V.: Impact of DEM mesh size and soil map scale on SWAT runoff, sediment, and NO3-N loads predictions, J. Hydrol., 312, 207-222, 2005.

Christensen, J. H. and Christensen, O. B.: A summary of the PRUDENCE model projections of changes in European climate by the end of this century, Clim. Change, 81(1), 7-30, 2007.

Döll, P. and Fiedler, K.: Global-scale modeling of groundwater recharge, Hydrol. Earth Syst. Sci., 12, 1-23, 2008, http://www.hydrol-earth-syst-sci.net/12/1/2008/.

Döll, C. and Döll, P.: Modellierung der Problemwahrnehmungen und Handlungen von Akteuren im Problemfeld "Mobile organische Fremdstoffe in Gewässern", in: Modellierung und Simulation komplexer geographischer Systeme, edited by: Mandel, P. and Koch, A., Salzburg (Salzburger Geographische Arbeiten, 43), 59-75, 2008.

Döll, C. and Döll, P.: Akteursanalyse und -modellierung im Rahmen des Projektes "Integrierte Analyse von mobilen, organischen Fremdstoffen in Fließgewässern”. In: Wittmann, J., Müller, M. (eds.): Simulation in Umwelt- und Geowissenschaften, Workshop Leipzig 2006, Shaker Verlag, Aachen, 109-118, 2006.

Döll, P., Kaspar, F., and Lehner, B.: A global hydrological model for deriving water availability indicators: model tuning and validation. J. Hydrol., 270, 105-134, 2003.

Döll, P. and Krol, M.: Integrated scenarios of regional development in two semi-arid states of Northeastern Brazil, Integr. Assess., 3, 308-320, 2002

Döll, P. and Fohrer, N.: Modellierung von Wasser- und Stofftransport in großen Einzugsgebieten - Stand der Forschung und Perspektiven, Hydrologie und Wasserbewirtschaftung, 43, 191-196, 1999.

Doherty J. and Johnston, J. M.: Methodologies for calibration and predictive analysis of a watershed model, J. Am. Water. Resour. Assoc., 251-265, 2003.

Ebenhöh, E. and Pahl-Wostl, C.: Agent behavior between maximization and cooperation, Rational. Soc., 20, 227-252, 2008.

Fekete, B. M., Gibson, J. J., Aggarwal, P., and Vörösmarty, C. J.:
Application of isotope tracers in continental scale hydrological modeling, J. Hydrol., 330, 444-456, 2006.

Fohrer, N. and Döll, P.: Modellierung des Wasser- und Stofftransports in großen Einzugsgebieten, Kassel University Press, 1999.

Franks, S. W., Beven, K. J., Quinn P. F., and Wright I. R.: On the sensitivity of soil-vegetation-atmosphere transfer (SVAT) schemes: Equifinality and the problem of robust calibration, Agric. For. Meteorol., 86, 63-75, 1997.

Gerold, G.: Heterogenität landschaftshaushaltlicher Wasser- und Stoffumsätze in Einzugsgebieten, EcoRegio 8, Göttingen, 2000.

Gerten, D., Schaphoff, S., Haberlandt, U., Lucht, W., and Sitch, S.: Terrestrial vegetation and water balance: hydrological evaluation of a dynamic global vegetation model, J. Hydrol., 286, 249-270, 2004.

Graham, L. P., Hagemann, S., Jaun S., and Beniston, M.: On interpreting hydrological change from regional climate models. Clim. Change, 81(1), 97-122, 2007.

Haberlandt, U., Krysanova, V., and Bárdossy, A.: Assessment of nitrogen leaching from arable land in large river basins, Part II: Regionalisation using fuzzy rule based modelling. Ecol. Model., 150, 277-294, 2002.

Haddeland, I., Skaugen, T., and Lettenmaier, D. P.: Hydrologic effects of land and water management in North America and Asia: 1700-1992. Hydrol. Earth. Syst. Sci., 11, 1035-1045, 2007.

Hagemann, S.: An improved land surface parameter dataset for global and regional climate models. Max Planck Institute for Meteorology Report 336, available from MPI for Meteorology, Bundesstr. 53, 20146 Hamburg, Germany, 2002.

Hagemann, S. and Jacob, D.: Gradient in the climate change signal of European discharge predicted by a multi-model ensemble. Clim. Change, 81(1), 309-327, 2007.

Hare, M. and Deadman, P.: Further towards a taxonomy of agentbased simulation models in environmental management, Mathematics and Computers in Simulation, 64, 25-40, 2004.

Haverkamp, S., Fohrer, N., and Frede, H.G.: Assessment of the effect of land use patterns on hydrologic landscape functions: a comprehensive GIS-based tool to minimize model uncertainty resulting from spatial aggregation, Hydrol. Process., 19, 715727, 2005.

Hennrich, K., Rode, M., and Bronstert, A.: 6. Workshop zur großskaligen Modellierung in der Hydrologie - Flussgebietsmanagement, Kassel University Press, 2003.

Kaspar, F.: Entwicklung und Unsicherheitsanalyse eines globalen hydrologischen Modells, Dissertation, Department of Natural Sciences, University of Kassel, Kassel, 2003.

Kennen, J. G., Kauffman, L. J., Ayers, M. A., Wolock, D. M., and Colarullo, S. J.: Use of an integrated flow model to estimate ecologically relevant hydrologic characteristics at stream biomonitoring sites, Ecol. Mod., 211, 57-76, 2008.

Krause, P., Bongartz, K., and Flügel, W.-A.: Preface "Model integration and development of modular modelling systems", Adv Geosci., 4, 1-2, 2005

Krol, M. S., Jaeger, A., and Bronstert, A.: Integrated Modelling of Climate Change Impacts in North-Eastern Brazil, in: Global Change and Regional Impacts, edited by: Gaiser, T., Krol, M., Frischkorn, H., and de Araujo, J. C., Springer, Heidelberg, Berlin, 43-56, 2003.

Kuo, W. L., Steenhuis, T. S., McCulloch, C. E., Mohler, C. L., Weinstein, D. A., DeGloria, S. D., and Swaney, D. P.: Effect of 
grid size on runoff and soil moisture for a variable-source-area hydrology model, Water Resour. Res., 35, 3419-3428, 1999.

Leavesley, G. H., Markstrom, S. L., Viger, R. J., and Hay, L. E.: USGS Modular Modeling System (MMS) - Precipitation-Runoff Modeling System (PRMS) MMS-PRMS, in: Watershed Models, edited by: Singh, V., and Frevert, D., CRC Press, Boca Raton, USA, 159-177, 2005.

Lindenschmidt, K.-E., Hattermann, F., Mohaupt, V., Merz, B., Kundzewicz, Z. W., and Bronstert, A.: Preface "Large-scale hydrological modelling and theWater Framework Directive and Floods Directive of the European Union - 10th Workshop on Large-Scale Hydrological Modelling", Adv. Geosci., 11, 1-6, 2007

Lindenschmidt, K.-E.: The effect of complexity on parameter sensitivity and model uncertainty in river water quality modelling, Ecol. Model., 190, 72-86, 2006.

Ludwig, R., Mauser, W., and Reichert, D.: 7. Workshop zur großskaligen Modellierung in der Hydrologie - Neue methodische Ansätze zur Modellierung der Wasser- und Stoffumsätze in großen Einzugsgebieten, Kassel University Press, 2004.

Menzel, L.: Flächenhafte Modellierung der Evapotranspiration mit TRAIN (Areal modelling of evapotranspiration with TRAIN; in German), Summary Report No. 54, Potsdam-Institute for Climate Impact Research, 1999.

Muleta, M. K. and Nicklow, J. W.: Sensitivity and uncertainty analysis coupled with automatic calibration for a distributed watershed model, J. Hydrol., 306, 127-145, 2005.

Oki, T. and Kanae, S.: Global hydrological cycles and world water resources. Science, 313,, 1068-1072, 2006.

Petersen, G., Bast, H., and Fohrer, N.: Estimation of ungauged Bahr el Jebel flows based on upstream water levels and large scale spatial rainfall data, Adv. Geosci., 18, 9-13, 2008,

http://www.adv-geosci.net/18/9/2008/.

Peters-Lidard, C. D., Zion, M. S., and Wood, E. F.: A soilvegetation-atmosphere transfer scheme for modeling spatially variable water and energy balance processes, J. Geophys. Res., 102(D4), 4303-4324, 1997.

Portmann, F., Berkhoff, K., and Hunger, M.: Preface "Advances and visions in large-scale hydrological modelling - Proceedings of the 11th Workshop on Large-scale Hydrological Modelling", Adv. Geosci., 18, 1-2, 2008

Raddatz, T. J., Reick, C., Knorr, W., Kattge, J., Roeckner, E., Schnur, R., Schnitzler, K.-G., Wetzel, P., and Jungclaus, J.: Will the tropical land biosphere dominate the climate-carbon cycle feedback during the twenty-first century?, Clim. Dynam., 29, 565-574, 2007.

Rost, S., Gerten, D., Bondeau, A., Lucht, W., Rohwer, J., and Schaphoff, S.: Agricultural green and blue water consumption and its influence on the global water system. Water Resour. Res., 44, W09405, doi:10.1029/2007WR006331, 2008a.

Rost, S., Gerten, D., and Heyder, U.: Human alterations of the terrestrial water cycle through land management. Adv. Geosci., 18, 43-50, 2008b,

http://www.adv-geosci.net/18/43/2008/.

Saltelli, A., Chan, K., and Scott, E. M.: Sensitivity Analysis, John Wiley \& Sons, 2000.

Schmalz, B., Bieger, K., and Fohrer, N.: A method to assess instream water quality - the role of nitrogen entries in a North German rural lowland catchment, Adv. Geosci., 18, 37-41, 2008, http://www.adv-geosci.net/18/37/2008/.

Schulla, J.: Hydrologische Modellierung von Flußgebieten zur Abschätzung der Folgen von Klimaänderungen. Züricher Geographische Schriften, 69, 161 p. Geographisches Institut, ETH Zürich, 1997.

Seitzinger, S. P., Harrison, J. A., Dumont, E., Beusen, A. H. W., and Bouwman, A. F.: Sources and delivery of carbon, nitrogen, and phosphorus to the coastal zone: An overview of Global Nutrient Export from Watersheds (NEWS) models and their application, Global Biogeochem. Cycles, 19, GB4S01, doi:10.1029/2005GB002606, 2005.

Sitch, S., Smith, B., Prentice, I .C., Arneth, A., Bondeau, A., Cramer, W., Kaplan, J.O., Levis, S., Lucht, W., Sykes, M .T., Thonicke, K., and Venevsky, S.: Evaluation of ecosystem dynamics, plant geography and terrestrial carbon cycling in the LPJ dynamic global vegetation model. Global Change Biol., 9, 161$185,2003$.

Smakhtin, V., Revenga, C., and Döll, P.: A pilot global assessment of environmental water requirements and scarcity, Water Internat., 29, 307-317, 2004.

Stephan, K., Bormann, H., and Diekkrüger, B.: 5. Workshop zur Hydrologischen Modellierung. Möglichkeiten und Grenzen für den Einsatz hydrologischer Modelle in Politik, Wirtschaft und Klimafolgenforschung. Kassel University Press, 2002.

Sutmöller, J. and Raschke, E.: Modellierung in meso- bis makroskaligen Flusseinzugsgebieten - Tagungsband zum gleichnamigen Workshop am 16./17. November 2000 in Lauenburg, Berichte der GKSS, 2001/15, 2001.

Tang, Y., Reed, P., Wagener, T., and van Werkhoven, K.: Comparing sensitivity analysis methods to advance lumped watershed model identification and evaluation, Hydrol. Earth. Syst. Sci., 11, 793817, 2007.

Van der Sluijs, J. P., Craye, M., Funtowicz, S. O., Kloprogge, P., Ravetz, J., and Risbey, J. S.: Combining quantitative and qualitative measures of uncertainty in model based foresight studies: the NUSAP system, Risk Anal., 25, 481-492, 2005.

Van Drecht, G., Bouwman, A.F., Boyer, E.W., Green, P., and Siebert, S.: A comparison of global spatial distributions of nitrogen input for nonpoint sources and effects on river nitrogen export, Glob. Biogeochem. Cycles, 19, GB4S06, doi:10.1029/2005GB002454, 2005.

Viney, N. R., Croke, B.F.W., Breuer, L., Bormann, H., Bronstert, A., Frede, H., Gräff, T., Hubrechts, L., Huisman, J. A., Jakeman, A. J., Kite, G. W., Lanini; J., Leavesley, G., Lettenmaier, D. P., Lindström, G., Seibert; J., Sivapalan, M., and Willems, P.: Ensemble modelling of the hydrological impacts of land use change, in: MODSIM 2005 International Congress on Modelling and Simulation, edited by: Zerger, A. and Argent, R. M., Modelling and Simulation Society of Australia and New Zealand, December, 2967-2973, http://www.mssanz.org.au/modsim05/papers/viney. pdf, 2005.

Visser, H. and de Nijs, T.: The Map Comparison Kit, Environ. Model. Softw., 21, 346-358, 2006.

Wagner, W., Naeimi, V., Scipal, K., de Jeu, R., and MartínezFernández, J.: Soil moisture from operational meteorological satellites, Hydrogeol. J., 15, 121-131, 2007.

Wagner, W., Scipal, K., Pathe, C., Gerten, D., Lucht, W., and Rudolf, B.: Evaluation of the agreement between the first global remotely sensed soil moisture data with model 
and precipitation data, J. Geophys. Res., 108(D19), 4611, doi:10.1029/2003JD003663, 2003.

Weiß, M. and Menzel, L.: A global comparison of four potential evapotranspiration equations and their relevance to stream flow modelling in semi-arid environments, Adv. Geosci., 18, 15-23, 2008 ,

http://www.adv-geosci.net/18/15/2008/.

Wollheim W. M., Vörösmarty. C. J., Bouwman, A. F., Green, P., Harrison, J., Linder, E., Peterson, B. J., Seitzinger, S. P., and Syvitski, J. P. M.: Global N removal by freshwater aquatic systems using a spatially distributed, within-basin approach, Global Biogeochem. Cycles, 22, GB2026, doi:10.1029/2007GB002963, 2008 .
Zhang, J. and Döll, P.: Assessment of ecologically relevant hydrological change in China due to water use and reservoirs, Adv. Geosci., 18, 25-30, 2008, http://www.adv-geosci.net/18/25/2008/.

Zhang, X., Hörmann, G., and Fohrer, N.: An investigation of the effects of model structure to reduce discharge simulation uncertainty in two catchments, Adv. Geosci., 18, 31-35, 2008, http://www.adv-geosci.net/18/31/2008/. 